\title{
Penerapan Bimbingan Kelompok untuk Meningkatkan Motivasi Belajar Bimbingan Konseling Peserta Didik SMP Negeri 4 Mataram
}

\author{
Siti Zuhaerani \\ SMP Negeri 4 Mataram, Kota Mataram - Provinsi NTB \\ Corresponding Author. Email: sitizuhaerani@gmail.com
}

\begin{abstract}
This study aims to determine the effectiveness of the implementation of group guidance in increasing the motivation to learn counseling guidance for students of SMP Negeri 4 Mataram. This research method uses classroom action research conducted in two cycles. The research instrument used observation and documentation. The data analysis technique used descriptive analysis. The results showed that in cycle II the indicators of the success of this study have been proven. So it can be concluded that the application of group guidance can increase the motivation to learn counseling guidance for class VIII. 2 students of SMP Negeri 4 Mataram.
\end{abstract}

\begin{abstract}
Abstrak: Penelitian ini bertujuan untuk mengetahui efektifitas pelaksanaan bimbingan kelompok dalam meningkatkan motivasi belajar bimbingan konseling peserta didik SMP Negeri 4 Mataram. Metode penelitian ini menggunakan penelitian tindakan kelas yang dilakukan sebanyak dua siklus. Instrumen penelitian ini menggunakan observasi dan dokumentasi. Teknik analisis data menggunakan analisis deskriptif. Hasil penelitian menunjukkan bahwa pada siklus II indikator keberhasilan penelitian ini telah terbukti. Sehingga dapat disimpulkan bahwa penerapan bimbingan kelompok dapat meningkatkan motivasi belajar bimbingan konseling peserta didik kelas VIII.2 SMP Negeri 4 Mataram.
\end{abstract}

Article History

Received: 29-02-2021

Revised: 07-03-2021

Published: 14-04-2021

Key Words:

Group Guidance,

Learning Motivation.

\section{Sejarah Artikel}

Diterima: 29-02-2021

Direvisi: 07-03-2021

Diterbitkan: 14-04-2021

\section{Kata Kunci:}

Bimbingan Kelompok, Motivasi Belajar.

How to Cite Zuhaerani, S. (2021). Penerapan Bimbingan Kelompok untuk Meningkatkan Motivasi Belajar Bimbingan Konseling Peserta Didik SMP Negeri 4 Mataram. Jurnal Teknologi Pendidikan : Jurnal Penelitian dan Pengembangan Pembelajaran, 6(1). doi:https://doi.org/10.33394/jtp.v6i1.3604

\section{Pendahuluan}

Pendidikan pada dasarnya merupakan proses untuk membantu manusia dalam mengembangkan potensi dirinya sehingga mampu menghadapi setiap perubahan yang terjadi. Tetapi proses pendidikan ini banyak yang mengatakannya sebagai proses belajar- mengajar, yang kemudian mempengaruhi jiwa pendidik sehingga yang dilakukannya adalah mengajarkan ilmu pengetahuan saja. Apa yang sering terjadi adalah hanya proses menstransfer ilmu pengetahuan kepada anak didik, soal pembentukan karakter dan moral tidak diutamakan (Sulistiya \& Jumailiyah, 2020; Gunawan \& Wulandari, 2017; Burhanudin, 2021).

Kemampuan memotivasi belajar mulai sangat diperlukan saat manusia memasuki masa remaja karena masa remaja merupakan masa yang penuh gejolak sehingga remaja sering dihadapkan pada persoalan-persoalan yang kompleks yang menjadi permasalahan yang dirasakan sulit oleh para remaja termaksud dalam hal belajar. Peserta didik SMP yang tergolong dalam usia peraliahan antara remaja dan kanak-kanak, mengalami proses perkembangan dan pertumbuhan serta mempunyai kecenderungan kurang stabil secara psikis banyak mengalami kesulitan dalam memotivasi cara belajar, akibatnya aktivitas belajarnya menurun dan prestasi yang diperolehnya kurang memuaskan. 
William Burton dalam Hamalik (2007) mengemukakan tujuan adalah sesuatu yang hendak dicapai dan akan memuaskan individu. Adanya tujuan akan mempengaruhi kebutuhan dan akan membangkitkan motivasi didalam diri. Sehingga seorang haruslah diberikan penguatan tentang tujuan dari apa yang ia lakukan untuk dapat meningkatkan motivasi pada dirinya. Seorang pelajar harus diberi sebuah pemahaman tentang tujuan belajar yang sedang ia tempuh untuk dapat meningkakan motivasi belajar. Menurut Hover (dalam Hamalik, 2007) mengemukakan prinsip-prinsip motivasi belajar sebagai berikut: Pujian lebih efektif daripada hukuman, Semua murid-murid mempunyai kebutuhan-kebutuhan psikologis (yang bersifat dasar) tertentu yang harus mendapat kepuasan, Motivasi yang berasal dari dalam individu lebih efektif daripada motivasi yang dipaksakan dari luar, Motivasi itu mudah menjalar atau tersebar terhadap orang lain, Pemahaman yang jelas terhadap tujuan-tujuan yang akan merangsang motivasi, dan Motivasi yang besar erat hubungannya dengan kreativitas murid.

Realita yang terjadi sekarang banyaknya peserta didik yang masih membutuhkan Bimbungan dan Konseling khususnya di SMP Negeri 4 Mataram, sebagai contoh realita yang masih terjadi pada kelas VIII.2 yang dikenal sebagai kelas unggulan, yang mana kelas VIII.2 terdiri atas peserta didik yang sering dengan malu dan kompetensi yang dapat diandalkan disamping itu juga berbagai karakter peserta didik dan peserta didik yang tentunya berbeda satu dan yang lainnya Prestasi intelegensi dapat dikatakan baik namun tidak lepas dan permasalahan seperti, kurang disiplhin ribut saat proses pembelajaran berlangsung dan juga motivasi belajar Bimbingan Konseling peserta didik yang tergolong kurang, meskipun mereka tergolong kelas unggulan.

Bimbingan konseling merupakan salah satu mata pelajaran yang dikhususkan untuk membina dan membimbing peserta didik siswi yang mempunyai masalah baik itu masalah internal maupun external yang mana BK atau Bimbingan Konseling mencakup hal-hal yang berkenaan dengan pribadi, kemasyarakatan, belajar, dan kaner peserta didik BK sangatlah penting untuk menujang dan memperbaiki sikap tingkah laku dan pribadi peserta didik yang keluar dan alur tata tertib ataupun aturan-aturan yang berlaku di SMP Negeri 4 Mataram.

Berdasarkan paparan permasalahan dan pentingnya mata pelajaran BK diatas, maka penelitian ini mencoba untuk meningkatkan motivasi belajar Bimbingan Konseling peserta didik kelas VIII.2 SMP Negeri 4 Mataram melalui sebuah strategi pembelajaran yakni Bimbingan Kelompok. Dalam penelitian ini bermaksud membagi peserta didik dalam kelompok guna menjadikan peserta didik lebih aktif dan lebih leluasa dalam belajar Bimbingan Konseling karena dengan bimbingan kelompok guru akan lebih mudah memotivasi peserta didik.

\section{Metode Penelitian}

Penelitian ini merupakan penelitian tindakan kelas yang dilaksanakan di kelas VIII.2 SMP Negeri 4 Mataram. Jumlah peserta didik sebanyak 32 peserta didik terdiri dari 17 orang peserta didik laki laki dan 15 orang peserta didik perempuan yang tergabung dalam I rombongan belajar. Penelitian ini dilakukan dalam empat tahap penelitian tindakan bimbingan konseling yang terdiri dari perencanaan, pelaksanaan tindakan, dan diikuti dengan pengamatan yang sistematik terhadap hasil tindakan yang dilakukan dan refleksi yang dilakukan berdasarkan hasil pengamatan dan kemudian diulangi lagi dari tahapan awal perencanaan tindakan berikutnya (Arikunto, 2009).

Penelitian ini direncanakan sebanyak 2 (dua) siklus, dengan lama waktu pembimbingan 1 jam sesuai dengan jadwal pembelajaran kelas VIII.2 SMP Negeri 4 Mataram. Jika pada siklus I (satu) indikator keberhasilan/indikator kinerja belum tercapai maka penelitian 
dilanjutkan kesiklus berikutnya. Tetapi bilamana pada siklus II indikator keberhasilan/indikator kinerja sudah tercapai maka penelitian dihentikan.

Teknik analisis data dalam PTK dapat dilakukan dengan analisis kualitatif dan analisis kuantitatif. Analisis data kualitatif digunakan untuk mendeskripsikan peningkatan proses konseling khususnya berbagai tindakan yang dilakukan peneliti sedangkan analisis data kuantitatif digunakan untuk menganalisis peningkatan motivasi belajar peserta didik sebagai pengaruh dari setiap tindakan yang dilakukan. Adapun indikator keberhasilan penelitian ini yakni; (1) Proses pembimbingan kelompok dinyatakan telah berhasil jika skor rata-rata yang diperoleh pembimbing (Peneliti) maupun terbimbing (peserta didik kelas VIII.2 SMP Negeri 4 Matram) 4,0 (empat koma nol/katagon baik). (2) Motivasi belajar bimmgan konseling (BK) dinyatakan telah berhasil jika perolehan skor rata- rata peserta didik $\geq 4,0$ (baik), dan didukung oleh keberhasilan secara individual mengalami peningkatan dari siklus 1 ke siklus berikutnya.

\section{Hasil Penelitian dan Pembahasan Deskripsi Siklus I \\ Perencanaan}

Pada tahapan ini, peneliti melakukan kegiatan-kegiatan berikut 1) Penyusunan pelaksanaan rencana pembimbingan (RPP), 2) menyiapkan alat dan sumber bahan yang diperlukan dalam penelitian, 3) menyusun instrument observasi guru dan Peserta didik, 4) menysum pedoman analisis hasil penelitian dan 5) penentuan jadwal kegiatan penelitian.

\section{Pelaksanaan Tindakan}

Pada tahapan ini peneliti melakukan bimbingan melalui kegiatan nyata sebagai berikut: 1) guru BK selaku peneliti menyampaikan materi bimbingan dengan berbagai pendekatan, 2) dilanjutkan dengan Tanya jawab sekta materi bimbingan konseling yang disajikan.

\section{Pengamatan}

Observasi guru memperoleh skor rata-rata pertemuan I $(3,11)$ dan pertemuan II $(3,28)$. Observasi peserta didik memperoleh skor rata-rata pertemuan I $(3,26)$ dan pertemuan II $(3,35)$. Dan hasil belajar diperoleh dari tugas dan tes tertulis masing-masing memperoleh nilai sebesar $(67,38)$ dan $(67,69)$.

\section{Refleksi}

1) Renungan atas perolehan data hasil observast guru, observasi peserta didik, dan hasil kerja peserta didik

2) Memecahkan dengan indicator keberhasilan. selanjutnya merencanakan perbaikan dan penyempurnaan jents tindakan agar pada siklus berikutnya memperoleh hasil yang di harapkan

3) Gunu diberikan saran dan perbaikan oleh observer dalam melaksanakan tindakan berikutnya

4) Guru diberikan reward oleh observer atas perolehan data hasil penelitian data pada siklus

5) Guru menyusun rencana tindak lanjut yang lebih baik sesuai dengan saran dari observer.

\section{Deskripsi Siklus II}

\section{Perencanaan}

Pada tahapan ini kegiatan peneliti mah sama dengan yang dilakukan pada siklus I yaitu 1) menyusun RPP, 2) Menyiapkan alat bahan sumber yang diperlukan dalam penelitian, 3) menyusun instrument observasi guru dan peserta didik, 1) menyusun pedoman analisis hasil penelitian, dan 5) penentuan jadwal kegiatan tatap muka. 


\section{Pelaksanaan Tindakan}

Pada tahapan ini peneliti menyampaikan materi bimbingan konseling (BK) secara singkat dilanjutkan dengan Tanya jawab sekilas materi bimbingan. Pada tahapan ini guru melaksanakan bimbingan konseling (BK) secara berkelompok Peserta didik masih pada posisi kelompok sebagaimana pada siklus I setiap peserta didik diberikan tugas untuk menjawab soal yang sudah diberikan oleh guru BK Secara berkelompok soal dipecahkan bersama-sama tetapi setiap individu menulis sesuai dengan tingkat pemahaman masingmasing. Guru berkeliling membimbing peserta didik dalam kelompok sambil memberikan penguatan kepada semua kelompok atas hasil kerjanya. Hasil kerja kelompok yang dilaporkan secara individual dikumpulkan untuk dinilai oleh guru dan dunia sampai dimana dampak positif dan peningkatan motivasi belajar siswa selama proses bimbingan konseling (BK) berjalan.

\section{Pengamatan}

Observasi guru memperoleh skor rata-rata pertemuan I $(4,06)$ dan pertemuan II $(4,50)$. Observasi peserta didik memperoleh skor rata-rata pertemuan I $(4,24)$ dan pertemuan II $(4,38)$. Dan hasil belajar diperoleh dari tugas dan tes tertulis masing-masing memperoleh nilai sebesar $(81,50)$ dan $(87,81)$.

\section{Refleksi}

1) Renungan atas hasil perolehan data observast guna maupun observasi peserta didik serta nilai tata kata hasil kerja individual yang selanjutnya di cocokkan dengan indicator keberhasilan.

2) Karena hasil refleksi sudah menggambarkan keberhasilan yang dibuktikan dengan ketercapaian indicator keberhasilan, peneliti merencanakan untuk menghentikan penelitian

3) Guru mendapat saran perbaikan, hal-hal kecil yang ditemukan selama proses penelitian

4) Guru diberikan rewardpengetahuan atas keberhasilannya pada siklus II telah mampu melewati indicator keberhasilan yang direncanakan

5) Karena indicator keberhasilan telah terpenuhi. Peneliti menghentikan penelitian pada siklus

\section{Pembahasan}

\section{Siklus I}

\section{Perencanaan}

Pada tahapan mi peneliti telah berhasil melakukan kesiapan yang diperlukan dalam pelaksanaan penelitian. Ada satu kendala yang dihadapi yaitu dalam menyusun pedoman analisis hasil periclitan Hal ini disebabkan karena peneliti merasa ragu apakah perlu dengan rumus statistic atau hanya dengan rumus deskriptif kualitatif. Dampaknya dalam pembuatan laporan agak terlambat.

\section{Pelaksanaan Tindakan}

Guru BK/peneliti berhasil menyampaikan materi bimbingan Konseling (BK), tetapi ada kendala yaitu sulit menyelesaikan materi bimbingan disertai dengan Tanya jawab. Faktor penyebabnya karena waktu jam tatap muka untuk BK hanya satu jam pelajaran (40 menit). Akibatnya proses Tanya jawab tidak tuntas. Solusi yang dilakukan oleh guru peserta didik dibenkan tugas terstruktur dan tugas tidak terstruktur yang dikerjakan diluar jam pelajaran. Hasilnya semua permasalahan dapat diminimalkan. Guru BK memimpin pelaksanaan diskusi kelompok dalam memecahkan permasalahan soal-soal secara berkelompok. Kendala yang dihadap kekurangan waktu karena yang disediakan hanya satu jam (40 menit). Akibatnya 
proses pembimbingan belum tuntas. Solusinya peserta didik diberikan tugas tenstruktur untuk menyelesaikan permasalahan selama proses pembimbingan. Hasilnya permasalahan yang belum tuntas menjadi tuntas.

\section{Pengamatan}

Hasil observasi guru oleh observer pada pertemuan I memperoleh rata-rata $(3,11)$, sedangkan pertemuan Il diperoleh skor rata rata $(3,28)$. Hasil laporan kerja kelompok yang dilaporkan secara individual dan hasil tes tertulis ini diperoleh nilai rata-rata masing-masing sebesar $(67,38)$ dan $(69,25)$. Perolehan nilai rata-rata hasil kerja individual ini merupakan dampak nyata dan peningkatan motivasi belajar BK peserta didik kelas VIII.2 semester satu Tahun Pelajaran 2019/2020 di SMP Negeri 4 Mataram. Perolehan nilai rata-rata bukan merupakan indicator keberhasilan terhadap peningkatan motivasi belajar BK, tetapi hanya dampak yang diperoleh dari proses bimbingan konseling.

\section{Refleksi}

Hasil observasi guru maupun observasi peserta didik dalam upaya peningkatan motivasi belajar bimbingan Konseling (BK) pada siklus I masih jauh dari Indicator keberhasilan yang telah ditetapkan. Indicator yang diharapkan $\geq 4,0$ (kategori baik), tetapi perolehan rata-rata skor guru baru mencapai $(3,20)$ sementara rata-rata perolehan skor peserta didik dalam upaya peningkatan motivasi belajar BK peserta didik kelas VIII.2 SMP Negeri 4 Mataram baru mencapai skor rata-rata $(3,31)$ dari indicator keberhasilan yang diharapkan $\geq$ 4,0 .

Karena siklus I indikatornya belum tercapai maka penelitian dilanjutkan pada siklus II dengan mengoptimalkan semua tindakan nyata dikelas semyatanya. Target peningkatan motivasi belajar BK peserta didik kelas VIII.2 semester satu tahun pelajaran2019/2020 adalah skor rata-rata peningkatan motivasi belajar BK peserta didik adalah $\geq 4,0$ (kategori baik) dan meningkatnya perolehan rata-rata tugas individual siklus II.

\section{Siklus II}

\section{Perencanaan}

Kegiatan yang dilakukan peneliti pada tahapan ini masih sama dengan yang dilakukan pada siklus I yaitu, 1) penyusunan rencana pelaksanaan pembimbingan (RPP), 2) menyiapkan alat dan sumber bahan yang diperlukan dalam penelitian, 3) menyasm instrumen observasi guru dan observasi peserta didik, 4) menyusun podoman analines hasil penelitian, dan 5) membuat jadwal kegiatan penelitian.

Dari kelima jenis kegiatan diatas peneliti tidak mengalami hambatan ataupun kesalahan Semua kegiatan lancar sesuai yang diharapkan. Hal ini dapat terlaksana karena kesalahankesalahan yang terjadi pada siklus I sudah di cari solusinya dan pemecahannya dengan jalan minta petunjuk dan saran dari pengawas pembimbing yang sekaligus sebagai observer, sehingga dalam perencanaan siklus I tidak mengalami hambatan.

\section{Pelaksanaan Tindakan}

Pada tahapan ini berbeda apa yang akan dilakukan pada pelaksanaan tindakan siklus 1 . Pada siklus II peneliti menyampaikan materi bimbingan Konseling (BK) dilanjutkan dengan Tanya jawab. Tetapi pada siklus II ini peneliti melakukan bimbingan secara berkelompok. Di dalam pembimbingan guru memberikan solusi terhadap kesulitan dan kesalahan yang dialami oleh kelompok. Hasil kerja kelompok diminta sama peserta didik membuat rangkuman sendiri sesuai dengan kayakinan dan pemahaman yang berbeda-beda.

\section{Pengamatan}

Hasil pengamatan observasi guru yang dilakukan oleh observer pada pertemuan I memperoleh skor rata-rata $(4,06)$ sedangkan pada pertemuan ke II memperoleh skor rata-rata 
$(4,50)$. Jadi rata-rata hasil observasi pada siklus II adalah (4,28)/kategori baik. Sedangkan hasil observasi peserta didik dalam upaya peningkatan motivasi belajar BK peserta didik kelas VIII.2 semester satu tahun ajaran pelajaran 2019/2020 di SMP Negeri 4 Mataram memperoleh skor ata-rata $(4,30) /$ kategori baik. Sebagai dampak nyata dari peningkatan motivasi belajar bimbingan konseling (BK) bagi peserta didik kelas VIII.2 adalah meningkatnya perolehan nilai rata-rata hasil kerja kelompok dan tes tertulis yang di peroleh peserta didik yaitu $(84,66)$.

\section{Refleksi}

Setelah ditelaah data hasil observasi guru dan observaasi peserta didik tentang peningkatan motivasi belajar peserta didik perolehan nilai rata-rata sebagai dampak dan peningkatan motivasi belajar bimbingan konseling (BK), semuanya sudah melewati dan indicator keberhasilan. Peneliti melanjutkan dengan menyusun laporan tentang hasil penelitian tindakan kelas (PTK) sebagai bukti bahwa indicator keberhasilan telah tercapai pada siklus II. Karena indicator keberhasilan telah tercapai maka penelitian tindakan kelas (PTK) dinyatakan "BERHASIL" dan dihentikan pada siklus II.

Perolehan data hasil penelitian dari siklus I sampai siklus II, dapat dilihat pada paparan data sebagai berikut:

Tabel 1. Data penelitian dari siklus I sampai siklus II

\begin{tabular}{|c|l|c|c|c|c|c|c|}
\hline \multirow{2}{*}{ No } & \multicolumn{1}{|c|}{ Jenis Kegiatan } & \multirow{2}{*}{ IK } & \multicolumn{2}{|c|}{ Siklus I } & \multicolumn{2}{|c|}{ Siklus II } & \multirow{2}{*}{ Keterangan } \\
\cline { 4 - 7 } & & & I & II & I & II & \\
\hline 1. & Hasil Observasi Guru & $\geq 4,0$ & 3,11 & 3,28 & 4,06 & 4,50 & Tuntas \\
\hline 2. & Hasil Observassi Peserta didik & $\geq 4,0$ & 3,26 & 3,35 & 4,24 & 4,36 & Tuntas \\
\hline 3. & Hasil Kerja Individual & $\geq 75,00$ & 67,38 & - & 81,50 & - & Meningkat \\
\hline 4. & Hasil Tes tertulis & & - & 69,25 & - & 87,81 & Meningkat \\
\hline
\end{tabular}

\section{Kesimpulan}

Kesimpulan yang diperoleh dari hasil penelitian ini menunjukkan bahwa pada siklus II indikator keberhasilan penelitian ini telah terbukti. Sehingga dapat disimpulkan bahwa penerapan bimbingan kelompok dapat meningkatkan motivasi belajar bimbingan konseling peserta didik kelas VIII.2 SMP Negeri 4 Mataram.

\section{Saran}

Adapun saran yang disampaikan berdasarkan hasil penelitian ini adalah; (1) Kepada guru BK/teman sejawat disarankan untuk melakukan penelitian tindakan kelas (PTK) dalam upaya untuk meningkatkan motivasi belajar dan atas hasil belajar peserta didik yang dibinanya. (2) Kepada semua peserta didik supaya membiasakan untuk belajar dalam kelompok kecil/diskusi kelompok. Karena dengan belajar kelompok permasalahan yang berat dan dapat dipecahkan/di selesaikan secara bersama-sama. 


\section{Daftar Pustaka}

Arikunto, S. (2006). Prosedur Penelitian Suatu Pendekatan Praktik. Jakarta: Rineka Cipta

Burhanuddin, H. (2021). Optimalisasi Layanan Bimbingan Kelompok untuk Meningkatkan Kebiasaan Siswa Bertanya dalam Proses Pembelajaran di SMK Negeri 4 Gowa. Jurnal Paedagogy, 8(1), 57-66. doi:https://doi.org/10.33394/jp.v8i1.3238

Gunawan, I., Hartati, A., \& Mulachela, F. (2020). Pengaruh Konseling Kelompok Terhadap Perilaku Agresif Siswa di SMKN 4 Mataram. Jurnal Paedagogy, 7(4), 385-392. doi:https://doi.org/10.33394/jp.v7i4.2881

Gunawan, I., \& Wulandari, J. (2017). Pengaruh Teknik Biblioterapi Terhadap Kesadaran Diri Siswa. Jurnal Kependidikan: Jurnal Hasil Penelitian dan Kajian Kepustakaan di Bidang Pendidikan, Pengajaran dan Pembelajaran, 3(1). doi:https://doi.org/10.33394/jk.v3i1.475

Hamalik, Oemar. (2007). Proses Belajar Mengajar. Jakarta: PT Bumi Aksara.

Serikandi, B. (2020). Upaya Meningkatan Motivasi Belajar Siswa Melalui Layanan Bimbingan Kelompok di Kelas XII-IIS-1 SMA Negeri 1 Pujut. Jurnal Paedagogy, 7(2), 78-89. doi:https://doi.org/10.33394/jp.v7i2.2498

Sulistiya, E., \& Jumailiyah, J. (2020). PENGARUH KONSELING REALITA TERHADAP PEMBENTUKAN KEMANDIRIAN PADA SISWA SMPN 2 KURIPAN. Jurnal Paedagogy, 3(2), 52-58. doi:https://doi.org/10.33394/jp.v3i2.3037

Winkel, WS. (200s) Bimbingan dan Konseling di Institusi Pendidikan, Edisi Revisi. Jakarta: Gramedia

Sardiman. (2011). Interaksi dan Motivasi Belajar Mengajar. Jakarta: PT Raja Grafindo Persada

Rai Indrayasa, Made. (2012). Penerapan Bimbingan Kelompok Dalam Rangka Meningkatkan Sikap Kepemimpinan Pada Peserta didik Kelas VIII SMP Laboratorium Undiksha Singaraja Tahun Pelajaran 20122013 Skripsi (tidak diterbitkan) Jurusan BK FIP Undiksha

Zultoni, J., \& Herna Astuti, F. (2020). PENGARUH LAYANAN KONSELING INDIVIDU TERHADAP PENYESUAIAN DIRI SISWA DI SMAN 2 PRINGGARATA. Jurnal Paedagogy, 3(2), 45-51. doi:https://doi.org/10.33394/jp.v3i2.3036 